\title{
Decreased hepatic glucagon responses in Type 1 (insulin-dependent) diabetes mellitus
}

\author{
L. Ørskov ${ }^{2}$, K. G.M.M.Alberti ${ }^{5}$, A.Mengel ${ }^{1}$, N.Møller ${ }^{1}$, O.Pedersen ${ }^{4}$, O. Rasmussen $^{1}$, T.Seefeldt ${ }^{2}$ and O. Schmitz $^{3}$ \\ ${ }^{1}$ Institute of Experimental Clinical Research, Aarhus University, ${ }^{2}$ Department of Medicine M, Randers Centralsygehus, Randers, \\ ${ }^{3}$ Department of Medicine III, Aarhus Amtssygehus, ${ }^{4}$ Hvidøre Hospital, Klampenborg, Denmark and \\ ${ }^{5}$ Department of Medicine, University of Newcastle, Newcastle-Upon-Tyne, UK
}

Summary. The effect of glucagon infusion on hepatic glucose production during euglycaemia was evaluated in seven Type 1 (insulin-dependent) diabetic patients and in ten control subjects. In the diabetic subjects normoglycaemia was maintained during the night preceding the study by a variable intravenous insulin and glucose infusion. During the study endogenous insulin secretion was suppressed by somatostatin $(450 \mu \mathrm{g} / \mathrm{h})$ and replaced by insulin infusion $\left(0.15 \mathrm{mU} \cdot \mathrm{kg}^{-1} \cdot \mathrm{min}^{-1}\right) .{ }^{3} \mathrm{H}$-glucose was infused for isotopic determination of glucose turnover. Plasma glucose was clamped at $5 \mathrm{mmol} / 1$ for $2 \mathrm{~h} 30 \mathrm{~min}$ and glucagon $(1.5 \mathrm{ng}$. $\left.\mathrm{kg}^{-1} \cdot \mathrm{min}^{-1}\right)$ was then infused for the following $3 \mathrm{~h}$. Hepatic glucose production and glucose utilisation were measured during the first, second and third hour of the glucagon infusion. Basal hepatic glucose production (just prior to glucagon infusion) was similar in diabetic $\left(1.2 \pm 0.3 \mathrm{mg} \cdot \mathrm{kg}^{-1} \cdot \mathrm{min}^{-1}\right)$ and control $\left(1.6 \pm 0.1 \mathrm{mg} \cdot \mathrm{kg}^{-1} \cdot \mathrm{min}^{-1}\right)$ subjects. In diabetic patients hepatic glucose production rose slowly to $2.1 \pm 0.5 \mathrm{mg} \cdot \mathrm{kg}^{-1} \cdot \mathrm{min}^{-1}$ during the first hours of glucagon infusion and stabilized at this level $\left(2.4 \pm 0.5 \mathrm{mg} \cdot \mathrm{kg}^{-1} \cdot \mathrm{min}^{-1}\right)$ in the third hour. In control subjects hepatic glucose production increased sharply to higher levels than in the diabetic subjects $\left(3.4 \pm 0.3 \mathrm{mg} \cdot \mathrm{kg}^{-1} \cdot \mathrm{min}^{-1}\right)$ during the first and second hour of glucagon infusion $(p<0.05)$ and then gradually fell $\left(2.9 \pm 0.4 \mathrm{mg} \cdot \mathrm{kg}^{-1} \cdot \mathrm{min}^{-1}\right)$ during the third hour. In conclusion, when stimulated with glucagon at a physiologic plasma concentration diabetic patients had 1) an overall reduced hepatic glucose production response and 2) an abnormal sluggish response pattern. These abnormalities may imply inappropriate counter-regulation following a hypoglycaemic episode.

Key words: Type 1 diabetes mellitus, Glucagon, Hepatic glucose production.
Hypoglycaemia is a frequent complication of Type 1 (insulin-dependent) diabetes mellitus, and $10 \%$ of patients on conventional insulin therapy suffer at least one severe episode per year [1]. The incidence of hypoglycaemia is reported to be increased approximately three-fold during intensive insulin therapy (multiple injection regimens) $[1,2]$.

Early studies of counter-regulation in short-term hypoglycaemia $[3,4]$ and more prolonged hyperinsulinaemia [5] as well as studies using the pituitary-adrenal-pancreatic clamp technique $[6,7]$ in more prolonged hypoglycaemia have shown that counter-regulation initially mainly involves changes in hepatic glucose production (HGP). These changes are due predominantly to glucagon and epinephrine. With more prolonged hypoglycaemia, suppression of glucose utilisation becomes manifest due to the increasing roles of growth hormone (GH) and cortisol $[8,9]$. A glucose autoregulatory effect on the liver as well as in the periphery has also been implicated $[10,11]$. In the diabetic patient, in whom counter-regula- tory responses are of particular importance, various defects have been reported to enhance the tendency to hypoglycaemia $[1,12,13]$. These abnormalities include the presence of insulin antibodies [14] and selective impaired glucagon response to hypoglycaemia after about 5 years of diabetes [14], in Type 2 (non-insulin-dependent) [15] as well as Type 1 diabetes mellitus [14]. Furthermore, after 5 to 10 years of disease a diminished epinephrine response has also been reported in some patients $[16,17]$.

With a defective hormonal response to hypoglycaemia the sensitivity to physiological levels of glucagon (and epinephrine) becomes particularly important. However, this issue has not previously been investigated in detail.

Apart from an important function in the acute prevention/recovery from hypoglycaemia, glucagon is a primary determinant of HGP in the post-absorptive state and is responsible for the majority of glucose output [18]. It also plays a significant role in other situations where the need for glucose production is increased. During extended 
exercise increments in glucagon concentrations have been shown to increase HGP significantly in humans $[19,20]$. In the initial stages of starvation and after a protein rich meal glucagon has an essential function in securing glucose supply to the brain [21,22]. Also, it has been shown to be one of the factors responsible for stress-induced hyperglycaemia [23]. Basal plasma glucagon levels increase HGP mainly by stimulating glycogenolysis, whereas with higher plasma glucagon levels, a stimulatory effect on gluconeogenesis is also evident [24]. Small experimental increments in plasma gulcagon concentrations have been shown to have marked stimulatory effects on HGP [18].

The purpose of this study was to evaluate hepatic sensitivity to modest increments of glucagon in Type 1 diabetes.

\section{Subjects and methods}

\section{Subjects (Table 1)}

Seven C-peptide negative diabetic (six male, one female) and ten healthy subjects (nine male, one female) were studied. At that time the age of the diabetic subjects was $31 \pm 7$ years and the control subjects $27 \pm 1$ years. Height and weight were similar in the two groups. The control subjects were healthy volunteers, none had a family history of diabetes or were taking any drugs. The diabetic subjects were volunteers from the out-patient clinic of the participating hospitals. Apart from diabetes they had no other diseases and kidney function was normal.

Mean $\mathrm{HbA}_{1 \mathrm{C}}$ value of the diabetic subjects prior to the experiment described was $7.7 \pm 0.9 \%$ (range: $5.6-12 \%$ ). Mean duration of disease was $12 \pm 4$ years (range: $1-30$ years). Informed consent was obtained from all participants and the protocol of study was approved by the regional ethical committee.

\section{Experimental design (Fig.1)}

On the day before the study, the diabetic subjects received soluble insulin only. In the evening they were connected to a Biostator (Life Science Instruments, Miles Laboratories, Elkhart, Ind., USA) to obtain normoglycaemia by a feedback automated glucose controlled insulin infusion (Insulin Velosulin Human, Nordisk Gentofte A/S, Gentofte, Denmark). The double lumen catheter for continuous blood withdrawal by the Biostator was inserted into a forearm vein of the left arm, another catheter for intermittent blood sampling was placed in a wrist vein on the same side and a third catheter was placed in a right cubital vein for infusions. During the study the subjects kept the left hand and forearm in a heated plexiglas box to ensure arterialization of venous blood. The control subjects were admitted to hospital on the morning of the day of study.

Table 1. Clinical data of subjects studied

\begin{tabular}{lll}
\hline & $\begin{array}{l}\text { Type 1 } \\
\text { diabetic subjects }\end{array}$ & Control subjects \\
\hline Age (years) & $31 \pm 7$ & $27 \pm 1$ \\
Sex (male/female) & $6 / 1$ & $9 / 1$ \\
Height $(\mathrm{cm})$ & $175 \pm 5$ & $180 \pm 2$ \\
Weight $(\mathrm{kg})$ & $67 \pm 5$ & $71 \pm 4$ \\
BMI $\left(\mathrm{kg} / \mathrm{m}^{2}\right)$ & $21.9 \pm 0.7$ & $22.4 \pm 1$ \\
Diabetes duration (years) & $12 \pm 4$ & - \\
HbA $_{1 \mathrm{C}}(\%)$ & $7.7 \pm 0.9$ & - \\
\hline
\end{tabular}

Experimental design

$$
\left.\begin{array}{c}
\text { Glucagon } \\
\mathrm{ng} \cdot \mathrm{kg}^{-1} \cdot \mathrm{min}_{0}^{-1}
\end{array}\right]
$$
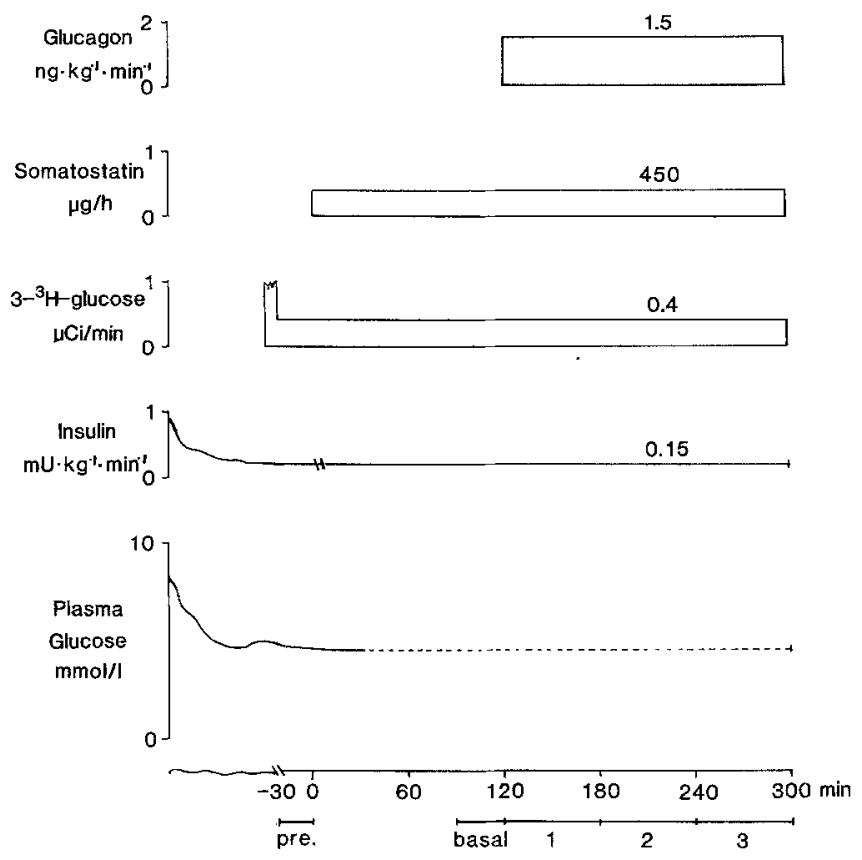

Fig. 1. Experimental design

At 07.30 hours $(t=-30)$ a primed $(40 \mu \mathrm{Ci})$, continuous $\left(0.4 \mu \mathrm{Ci} / \mathrm{min}\right.$ ) infusion of $3{ }^{3} \mathrm{H}$-glucose (New England Nuclear, Boston, Mass., USA) was started and continued throughout the study for isotopic determination of glucose turnover. $3-{ }^{3} \mathrm{H}$-glucose batches contained no radiochemical contaminants as assessed by high pressure liquid chromatography. From 08.00 hours $(t=0)$ somatostatin $(450 \mu \mathrm{g} / \mathrm{h})$ and insulin $\left(0.15 \mathrm{mU} \cdot \mathrm{kg}^{-1} \cdot \mathrm{min}^{-1}\right)$ were infused. At the same time plasma glucose was acutely clamped at $5 \mathrm{mmol} / \mathrm{l}$ and maintained at this level for $120 \mathrm{~min}$. At 10.00 hours an infusion of glucagon (Novo Industri A/S, Copenhagen, Denmark) (1.5ng. $\mathrm{kg}^{-1} \cdot \min ^{-1}$ ) was commenced. From this stage no upper limit was set for the plasma glucose level, but it was not allowed to fall below $5 \mathrm{mmol} / \mathrm{l}$. Blood for determination of plasma glucose, plasma glucose specific activity, serum insulin, serum C-peptide, plasma glucagon, serum $\mathrm{GH}$, serum non-esterified fatty acid (NEFA) and blood metabolites was drawn every $15 \mathrm{~min}$ throughout the study. Plasma glucose was determined every $5 \mathrm{~min}$ by a glucose analyzer. As shown in Figure 1 values from -30 to $0 \mathrm{~min}$ are designated as pre-values, whereas basal values refer to mean of blood samples taken during the last $30 \mathrm{~min}$ of the clamp, just prior to glucagon infusion $(90-$ $120 \mathrm{~min}$ ). Period 1 refers to $\mathrm{t} 120-180$, period 2 to $\mathrm{t} 180-240$ and period 3 to $240-300 \mathrm{~min}$ (i.e. the $1 \mathrm{st}, 2 \mathrm{nd}$ and $3 \mathrm{rd}$ hour of glucagon infusion).

\section{Analytical methods}

Plasma glucose was determined by a glucose oxidase method, and serum GH and plasma pancreatic glucagon by RIA using wick chromatography [25]. Free insulin was measured by RIA as described previously [26]. Serum C-peptide was assayed employing a commercial kit (Immunonuclear Corp., Stillwater, Minn., USA) and serum NEFA according to Ho and Meng [27]. Blood 3-hydroxybutyrate $(\mathrm{BOH})$, glycerol, lactate, and alanine were assayed by automated enzymatic fluorometric methods [28]. For determination of tritiated glucose activity plasma was deproteinized using $0.3 \mathrm{~mol} / \mathrm{Ba}(\mathrm{OH})_{2}$ and $0.3 \mathrm{~mol} / 1 \mathrm{ZnSO}_{4}$, after which the supernatant was evaporated under vacuum, resuspended in distilled water, and counted by a liquid scintillation counter after the addition of $5 \mathrm{ml}$ Aqualuma Plus (Lumbac, Schaesburg, The Netherlands). 


\section{Calculations and statistical analysis}

The rates of total glucose appearance $(\mathrm{Ra})$ and total glucose disappearance $(\mathrm{Rd})$ were determined from tritiated glucose data in samples taken every $15 \mathrm{~min}$ in the basal period and throughout periods 1,2 and 3 . The values were calculated according to the non-steady-state equations of Steele et al. [29], using $200 \mathrm{ml} / \mathrm{kg}$ as the glucose distribution volume and 0.65 for the pool fraction. $\mathrm{Rd}$ values were corrected for urinary glucose losses. HGP was calculated by subtracting the glucose infusion rate from $R$.

All values are expressed as mean \pm SEM. Two-way analysis of variance (ANOVA) with repeated measures over one factor (time) was employed a priori to test for changes with time and between groups. If this test revealed significant differences the Student's $t$-test for paired and unpaired data was used to further assess differences between experiments.

\section{Results}

Glucose, hormones andmetabolites (Table 2, Figs. 2 and 3)

Pre-experimental (pre) values $(t:-30-0 \mathrm{~min})$ of plasma glucose were slightly higher in the diabetic group $(6.2 \pm 0.4$ vs $5.3 \pm 0.1 \mathrm{mmol} / 1, p<0.05)$, whereas prevalues of serum insulin, plasma glucagon and serum $\mathrm{GH}$ were similar. Pre-levels of serum C-peptide were significantly higher in the control subjects $(1.5 \pm 0.1$ vs $<0.7 \mathrm{pmol} / \mathrm{ml}$ ) (below lower detection limit); $p<0.05$.

Basal levels of plasma glucose, serum insulin, and plasma glucagon were similar in diabetic and healthy subjects (Fig.2).

In both groups plasma glucose increased with time $(p<0.01)$ the increase was significantly more pronounced in the control group $(p<0.01)$ (control subjects; from $5.2 \pm 0.1$ to $7.4 \pm 0.7 \mathrm{mmol} / 1$, diabetic subjects; from $5.2 \pm 0.1$ to $6.4 \pm 0.7 \mathrm{mmol} / \mathrm{l})$. Serum insulin and $\mathrm{GH}$ levels were stable and similar at basal levels during glucagon infusion. Plasma glucagon concentrations increased comparably in both groups (Table 2).

Basal serum NEFA and blood glycerol levels were similar in the two groups. During glucagon infusion a significant reduction of serum NEFA levels was seen in both

Table 2. Pre $(-30-0 \mathrm{~min})$, basal $(90-120 \mathrm{~min})$, period $1(120-$ $180 \mathrm{~min}$ ), period $2(180-240 \mathrm{~min})$ and period $3(240-300 \mathrm{~min})$ values of plasma glucose, glucagon, serum insulin, C-peptide and growth hormone $(\mathrm{GH})$ in seven Type 1 (insulin-dependent) diabetic and ten control subjects during euglycaemic clamping with infusion of glucagon

\begin{tabular}{llllll}
\hline & $\begin{array}{l}\text { Plasma } \\
\text { glucose } \\
\text { (mmol/l) }\end{array}$ & $\begin{array}{l}\text { Glucagon } \\
(\mathrm{ng} / \mathrm{l})\end{array}$ & $\begin{array}{l}\text { Insulin } \\
(\mathrm{mU} / \mathrm{l})\end{array}$ & $\begin{array}{l}\text { C-peptide } \\
(\mathrm{nmol} / \mathrm{l})\end{array}$ & $\begin{array}{l}\mathrm{GH} \\
(\mu \mathrm{g} / \mathrm{l})\end{array}$ \\
\hline Diabetic patients & & & & \\
Pre & $6.2 \pm 0.4$ & $34 \pm 8$ & $26 \pm 4$ & $<0.7$ & $1.07 \pm 0.21$ \\
Basal & $5.2 \pm 0.1$ & $18 \pm 5$ & $26 \pm 5$ & $<0.7$ & $0.70 \pm 0.17$ \\
Period 1 & $5.6 \pm 0.4$ & $41 \pm 8$ & $26 \pm 4$ & $<0.7$ & $0.62 \pm 0.11$ \\
Period 2 & $6.2 \pm 0.6$ & $42 \pm 6$ & $28 \pm 4$ & $<0.7$ & $0.84 \pm 0.25$ \\
Period 3 & $6.4 \pm 0.7$ & $46 \pm 5$ & $28 \pm 5$ & $<0.7$ & $0.96 \pm 0.17$ \\
Control subjects & & & & \\
Pre & $5.3 \pm 0.1$ & $40 \pm 6$ & $22 \pm 2$ & $1.49 \pm 0.14$ & $0.77 \pm 0.21$ \\
Basal & $5.2 \pm 0.1$ & $17 \pm 4$ & $25 \pm 2$ & $<0.7$ & $0.43 \pm 0.17$ \\
Period 1 & $6.3 \pm 0.4$ & $40 \pm 7$ & $23 \pm 2$ & $<0.7$ & $0.49 \pm 0.15$ \\
Period 2 & $7.4 \pm 0.6$ & $50 \pm 7$ & $27 \pm 3$ & $<0.7$ & $0.53 \pm 0.16$ \\
Period 3 & $7.4 \pm 0.7$ & $49 \pm 5$ & $28 \pm 4$ & $<0.7$ & $0.53 \pm 0.16$ \\
\hline
\end{tabular}
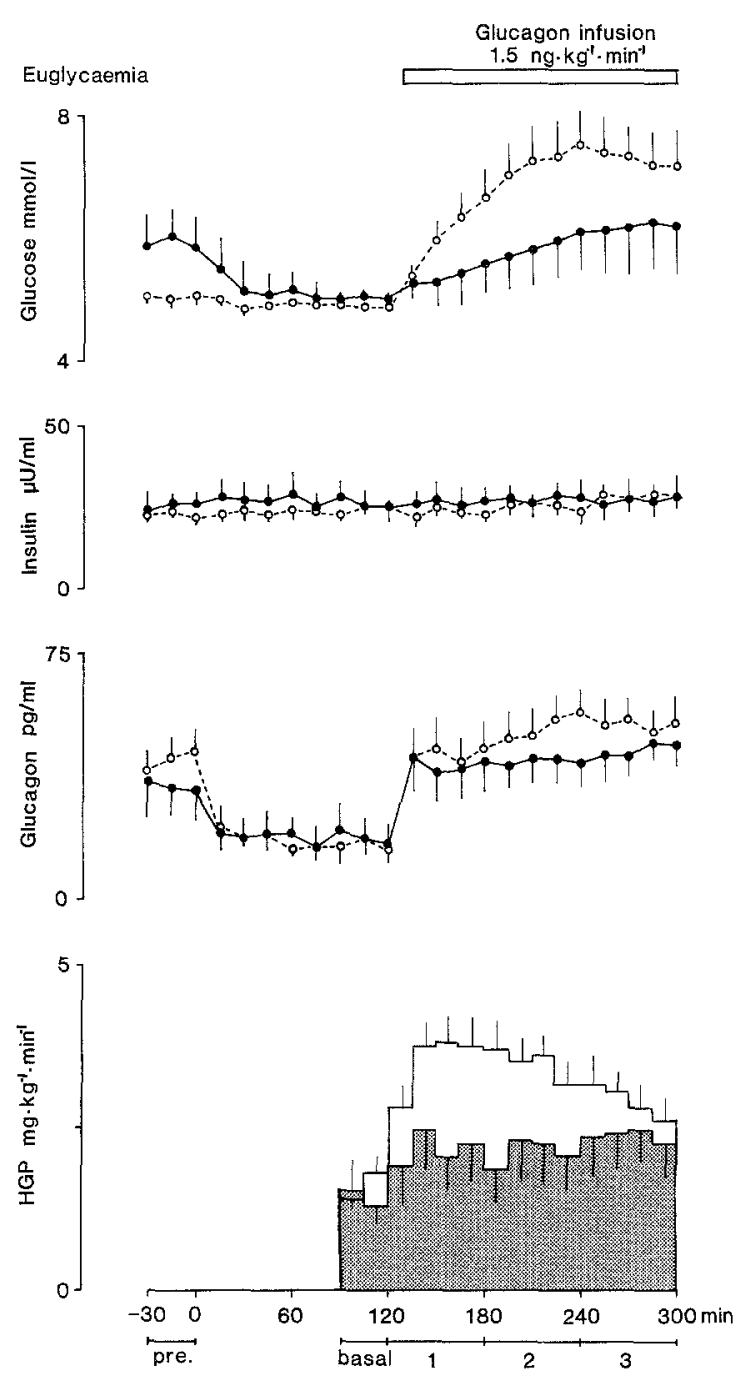

Fig. 2. Plasma glucose, insulin and glucagon concentrations and hepatic glucose production (HGP) rates in seven Type 1 (insulin-dependent) diabetic (closed circles and bars) and ten control subjects (open circles and bars) during glucagon infusion after $2 \mathrm{~h}$ of euglycaemia $(5 \mathrm{mmol} / \mathrm{l})$

groups. Blood glycerol levels were also similar in the two groups and tended to fall in both, but significantly only in the diabetic subjects (Fig. 3).

At all time points $\mathrm{BOH}$-values were higher in the diabetic group $(p<0.01)$; in both groups the $\mathrm{BOH}-1$ evel gradually fell to approximately half the starting value (55 \pm 12 to $23 \pm 6 \mu \mathrm{mol} / \mathrm{l}$ and $10 \pm 4$ to $4 \pm 1 \mu \mathrm{mol} / 1$, from basal to period 3 in diabetic patients and control subjects respectively); the decrease had already been initiated with the commencement of somatostatin/insulin infusion.

Blood lactate and alanine concentrations were similar in the two groups. Blood lactate levels were stable, whereas blood alanine levels rose very slightly in both groups (Fig. 3).

\section{Glucose kinetics (Fig. 2, Table 3)}

Basal hepatic glucose production was similar in the two groups $\left(1.2 \pm 0.3 \mathrm{vs} 1.6 \pm 0.1 \mathrm{mg} \cdot \mathrm{kg}^{-1} \cdot \mathrm{min}^{-1}\right.$, NS $)$. In both groups there was a time-dependent change in HGP 


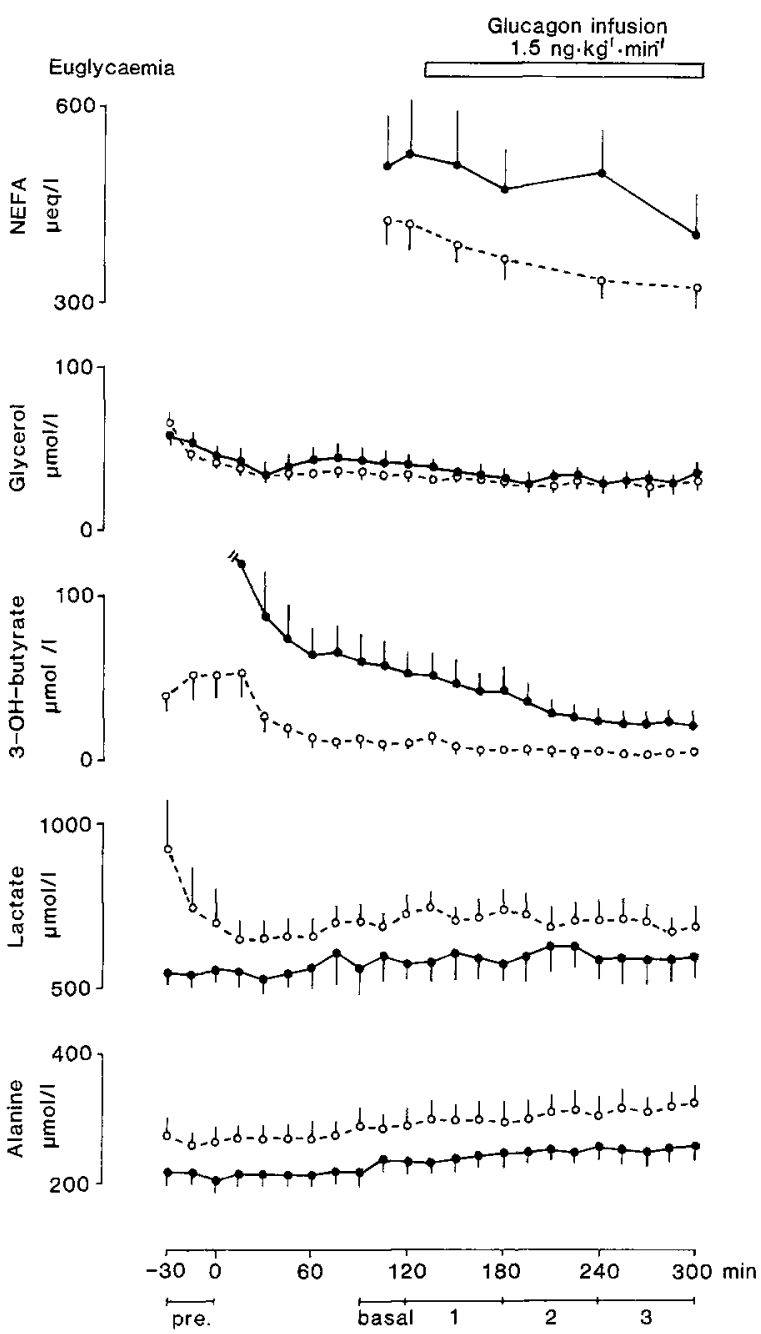

Fig.3. Concentrations of serum non-esterified fatty acid (NEFA), blood glycerol, 3-OH-butyrate, lactate and alanine in seven Type 1 (insulin-dependent) diabetic (closed circles) and ten control subjects (open circles) during glucagon infusion after $2 \mathrm{~h}$ of euglycaemia $(5 \mathrm{mmol} / \mathrm{l})$

$(p<0.05)$. ANOVA revealed the responses of the control subjects and diabetic patients to be significantly different $(p<0.05)$. The response in the control group to glucagon infusion was a sharp increase in HGP within minutes, which stayed at a stable high level $\left(\approx 3.5 \mathrm{mg} \cdot \mathrm{kg}^{-1} \cdot \mathrm{min}^{-1}\right)$ for approximately $100 \mathrm{~min}$ and then gradually decreased, without reaching the basal value within the observed time span. In the diabetic subjects, however, a totally different response was seen. Glucagon increased HGP only moderately and slowly (to $2.2 \pm 0.5 \mathrm{mg} \cdot \mathrm{kg}^{-1} \cdot \mathrm{min}^{-1}$, period 1 ) and this moderate increase was maintained throughout the infusion period. Following glucagon infusion there tended to be a time-dependent decrease in the glucose infusion rate $(\mathrm{M}),(0.05<p<0.1)$, this effect was significantly more pronounced in the control group $(p<0.05)$. Ra increased significantly in both groups with time $(p<0.01)$, no interaction was recorded.

Basal glucose utilisation (Rd) was similar, $2.5 \pm 0.2$ in the diabetic patients vs $2.7 \pm 0.1 \mathrm{mg} \cdot \mathrm{kg}^{-1} \cdot \mathrm{min}^{-1}$ in the control subjects, Rd increased with time in both groups $(p<0.01)$ with no significant difference between the increase of the groups.

\section{Discussion}

At the start of the studies (pre-values), plasma glucagon levels were comparably low in the diabetic patients and in the control subjects. This often occurs after overnight blood glucose regulation (Biostator), presumably due to the quite long-term blood glucose normalisation with input of adequate insulin and glucose. Somatostatin suppressed plasma glucagon levels further in both groups to approximately $18 \mathrm{pg} / \mathrm{ml}$, and the increment during glucagon infusion was $25-30 \mathrm{pg} / \mathrm{ml}$ ( $>100 \%$ increase), or approximately $25 \%$ above pre-values. Thus, what was studied here was the effect of an identical increase in plasma glucagon from low normal levels to the concentration usually found in Type 1 diabetic patients during everyday life.

When glucagon was infused the diabetic patients exhibited: 1(an overall reduced HGP response and 2) an abnormal response pattern with a more sluggish initial increase. These findings point towards a decreased HGP response to glucagon stimulation in the diabetic patients at euglycaemia, as both groups had similar plasma glucagon and insulin levels. No breakthrough of insulin release was evident in the control subjects, as assessed by serum insulin and C-peptide concentrations.

The finding of reduced HGP response is in apparent contrast to the results of Shamoon et al. [30], who found identical increases in HGP in diabetic and control subjects after glucagon infusion. In their study, however, secretion of insulin was not suppressed by somatostatin. In fact, the higher plasma insulin levels in the control subjects, in their study, with similar HGP rates, also point to a reduced HGP response to glucagon in the diabetic patients.

Diminished hepatic sensitivity to glucagon stimulation has also been found in another clinical condition, namely uraemia [31]. As in diabetes, patients with uraemia are exposed to chronic hyperglucagonaemia and hepatic 'insensitivity' to glucagon might be induced in an equivalent manner to the induction of insulin resistance. Rat hepatocytes from uraemic livers were found to be resistant to glucagon with regard to $\alpha$-aminoisobutyric acid uptake and this was found to be due to post-binding events [32].

It is obvious that the reduced HGP in the Type 1 diabetic subject may further attenuate the already com-

Table 3. Rates of total glucose appearance (Ra), total glucose disappearance (Rd), hepatic glucose production (HGP) and glucose infusion rate $(\mathrm{M})\left(\mathrm{mg} \cdot \mathrm{kg}^{-1} \cdot \mathrm{min}^{-1}\right)$ in seven Type 1 (insulin-dependent) diabetic and ten healthy subjects during euglycaemic clamping with infusion of glucagon

\begin{tabular}{lllll}
\hline & Ra & Rd & HGP & M \\
\hline Diabetic patients & & & & \\
Basal & $2.5 \pm 0.2$ & $2.5 \pm 0.2$ & $1.2 \pm 0.3$ & $1.3 \pm 0.5$ \\
Period 1 & $3.0 \pm 0.3$ & $2.7 \pm 0.3$ & $2.2 \pm 0.5$ & $0.9 \pm 0.4$ \\
Period 2 & $3.1 \pm 0.3$ & $2.9 \pm 0.3$ & $2.1 \pm 0.5$ & $1.0 \pm 0.6$ \\
Period 3 & $3.1 \pm 0.3$ & $3.0 \pm 0.3$ & $2.4 \pm 0.5$ & $0.7 \pm 0.5$ \\
Control subjects & & & & \\
Basal & $2.6 \pm 0.1$ & $2.7 \pm 0.1$ & $1.6 \pm 0.1$ & $1.2 \pm 0.2$ \\
Period 1 & $3.5 \pm 0.2$ & $3.0 \pm 0.2$ & $3.4 \pm 0.3$ & $0.4 \pm 0.1$ \\
Period 2 & $3.6 \pm 0.2$ & $3.4 \pm 0.2$ & $3.4 \pm 0.3$ & $0.3 \pm 0.1$ \\
Period 3 & $3.5 \pm 0.2$ & $3.6 \pm 0.2$ & $2.9 \pm 0.4$ & $0.4 \pm 0.2$ \\
\hline
\end{tabular}


promised recovery from a hypoglycaemic episode, created by persistent relative hyperinsulinaemia and a defective glucagon and epinephrine response.

The biochemical basis for the reduced and abnormal diabetic HGP response pattern is unexplained. Previous studies $[12,33,34]$ indicate that the initial response to glucagon is due to glycogenolysis. Subsequently gluconeogenesis is activated, at least with higher glucagon levels, and continues to increase, even when glycogenolysis and HGP are suppressed after a relatively short period. As the impaired diabetic HGP response in our study is most pronounced in the early response phase, this may indicate a reduced and sluggish activation of glycogenolysis at normal blood glucose levels. This cannot, however, be clarified on the basis of the present results.

Basal HGP levels were slightly, though not significantly higher in the control group. A true difference could have been caused by diminished glucagon sensitivity as well as increased hepatic insulin sensitivity in the diabetic group. However, the increase in HGP following glucagon infusion was much higher in the control subjects, which speaks against it being caused by insulin. Other studies have found hepatic insulin sensitivity to be decreased $[35,36]$ as well as increased [37] and the issue has not been sufficiently clarified. In the basal period, subjects were relatively glucagon deficient, and it cannot be excluded, that the lower response to glucagon in the diabetic subjects, may be overestimated by the lack of a physiological glucagon replacement prior to glucagon stimulation.

Of course, the existing shortcomings of the isotope dilution technique, whether caused by modelling errors or isotope discrimination, necessitates cautious interpretation of tracer-derived data. In the present study maximal glucose turnover rates were below the rate where suppression of HGP is at risk of being significantly overestimated $\left(<4 \mathrm{mg} \cdot \mathrm{kg}^{-1} \cdot \mathrm{min}^{-1}\right)$, and also the fact that glucose turnover rates tended to be higher in the control group, leading to greater suppression of HGP in this group, implies that our conclusion is reliable.

The fall in lipolysis, evident from the reduced blood glycerol levels prior to glucagon infusion, is presumably secondary to somatostatin/insulin infusion. When glucagon was also infused the decrease continued. This is in agreement with the results of Shulman et al. [38]. These authors found glucagon excess to be associated with inhibition of lipolysis, presumably secondary to glucagoninduced hyperglycaemia rather than a direct hormonal effect [38]. A direct lipolytic effect of glucagon has previously been described, but not in the presence of basal serum insulin levels $[39,40]$. The same combined effects of basal serum insulin levels, increasing blood glucose, and reduced supply of NEFA presumably account for the reduction in ketone body-levels found in both groups [40].

In conclusion, we have found 1) an overall reduced HGP response and 2) an abnormal response pattern to physiologic glucagon stimulation in Type 1 diabetic subjects. These abnormalities may lead to inappropriate counter regulation following a hypoglycaemic episode.

Acknowledgements. We thank Ms. I. Bisgaard and Ms. K. Nygaard for skilful technical assistance and Ms. A. Andersen for expert secre- tarial help. The study was supported by grants from the Danish Diabetes Association, the Danish Research Council and Aarhus University Research Council.

\section{References}

1. Gerich JE (1988) Glucose counter regulation and its impact in diabetes mellitus. Diabetes 37: 1608-1617

2. Thorsteinsson B, Pramming S, Lauritzen T, Binder C(1986) Frequency of daytime biochemical hypoglycaemia in insulin-treated diabetic patients in relation to daily median plasma glucose concentrations. Diab Med 3: 147-151.

3. Gerich J, Davis J, Lorenzi M et al. (1979) Hormonal mechanisms for the recovery from insulin induced hypoglycaemia in man. Am J Physiol 236: E380-E385

4. Gerich J, Cryer P, Rizza R (1980) Hormonal mechanisms in acute glucose counter regulation: the relative roles of glucagon, epinephrine, norepinephrine, growth hormone and cortisol. Metabolism 29: 1164-1175

5. Sacca L, Sherwin RS, Hendler R, Felig P (1979) Influence of continuous physiologic hyperinsulinaemia on glucose kinetics and counter regulatory hormone responses in normal and diabetic humans. J Clin Invest 63: 849-857

6. Rizza RA, Cryer PE, Gerich JE (1979) Role of glucagon, catecholamines and growth hormone in human glucose counter reguIation. J Clin Invest 64: 62-71

7. De Feo P, Periello G, Ventura MM et al. (1987) The pancreaticadrenocortical-pituitary clamp technique for study of counterregulation in humans. Am J Physiol 252: E565-570

8. De Feo P, Perriello G, Torlone E et al. (1989) Contribution of cortisol to glucose counterregulation in humans. Am J Physiol 257: E35-42

9. De Feo P, Perriello G, Torlone E et al. (1989) Demonstration of a role for growth hormone in glucose counterregulation. Am J Physiol 256: E835-843

10. Hansen J, Firth R, Haymond M, Cryer P, Rizza R (1986) The role of autoregulation of the hepatic glucose production in man's response to a physiological decrement in plasma glucose. Diabetes 35: 186-191

11. Bolli G, De Feo P, Perriello G et al. (1985) Role of hepatic autoregulation in defence against hypoglycaemia in human. J Clin Invest $75: 1623-1631$

12. Amiel SA, Tamborlane WV, Sacca L, Sherwin RS (1988) Hypoglycaemia and glucose counter regulation in normal and insulindependent diabetic subject. Diab Metab Rev 4: 71-89

13. Cryer PE, Binder C, Bolli GB et al. (1989) Hypoglycaemia in IDDM. A conference summary. Diabetes 38: 1193-1199

14. Bolli G, De Feo P, Campagnucci Pet al (1983) Abnormal glucose counter regulation in IDDM. Interaction of antiunsulin antibodies and impaired glucagon secretion. Diabetes 32: 134-141

15. Bolli G, Tsalikian E, Haymond M, Cryer P, Gerich J (1984) Defective glucose counter regulation after subcutaneous insulin in non-insulin-dependent diabetes mellitus. J Clin Invest 73: 15321541

16. White NH, Skor DA, Cryer PE, Levandoski LA, Bier DM, Santiago JV (1983) Identification of type 1 diabetic patients at increased risk for hypoglycaemia during intensive therapy. N Engl J Med 308: 485--491

17. Kennedy F, Bolli G, Go V, Cryer P, Gerich JE (1987) The significance of impaired pancreatic polypeptide and epinephrine responses to hypoglycaemia in patients with IDDM. J Clin Endocrinol Metab 64: 602-608

18. Cherrington AD, Stevenson RW, Steiner KE et al. (1987) Insulin, glucagon and glucose as regulators of hepatic glucose uptake and production in vivo. Diab Metab Rev 3: 307-332

19. Ahlborg G, Felig P, Hagenfeldt L, Hendler R, Wahren J (1974) Substrate turnover during prolonged exercise in man. J Clin Invest 53: 1080-1089 
20. Tuttle KR, Marker JC, Dalsby GP et al. (1988) Glucagon, not insulin may play a secondary role in defense against hypoglycemina during exercise. Am J Physiol 254: E713-E719

21. Unger RH, Orci L (1989) Glucagon secretion and metabolism in man. In: DeGroot LJ (ed) Endocrinology, 2nd edn. WB Saunders, pp 1318-1332

22. Hendrick GK, Frizzell RT, Williams PE, Cherrington AD (1990) Effect of hyperglucagonemia on hepatic glycogenolysis and gluconeogenesis after a prolonged fast. Am J Physiol 258: E841849

23. Shamoon H, Hendler R, Sherwin RS (1981) Synergistic actions among antiinsulin hormones in the pathogenesis of stress hyperglycemia in humans. J Clin Endocrinol Metab 52: 1235-1241

24. Cherrington AD, Liljenquist JE, Shulman GI, Williams PE, Lacy WE (1979) Importance of hypoglycaemia-induced glucose production during isolated glucagon deficiency. Am J Physiol 236: E263-E271

25. Ørskov H, Thomsen AG, Yde H (1968) Wick-chromatography for rapid and reliable immunoassay of insulin, glucagon and growth hormone. Nature 219: 193-195

26. Schmitz O, Alberti KGMM, Ørskov H (1984) Insulin resistance in uraemic insulin dependent diabetics. Effect of dialysis therapy as assessed by the artificial endocrine pancreas. Acta Endorcrinol (Copenh) 105: 371-378

27. Ho RJ, Meng HC (1996) A simple and ultrasensitive method for determination of free fatty acids by radiochemical assay. Anal Biochem 31: 226-236

28. Harrison J, Hodson AW, Skillin AW, Strappenbeck R, Ageus L, Alberti KGMM (1988) Blood glucose, lactate, pyruvate, glycerol, 3-hydroxybutyrate and acetoacetate measurements in man using a centrifugal analyser with a fluorimetric attachment. J Clin Chem Clin Biochem 26:141-146

29. Steele R (1959) Influence of glucose loading and of injected insulin on hepatic glucose output. Ann NY Acad Sci 82: 420-424

30. Shamoon H, Hendler R, Sherwin RS (1980) Altered responsiveness to cortisol, epinephrine and glucagon in insulin infused juvenile onset diabetics. A mechanism for diabetic instability. Diabetes 29:284-291

31. Schmitz O (1988) Peripheral and hepatic resistance to insulin and hepatic resistance to glucagon in uremic subjects. Acta Endocrinol (Copenh) 118: 125-134
32. Helenik TG, Sadel S, Caro JF (1984) The effects of chronic uremia on glucagon binding and action in isolated rat hepatocytes. Metabolism 33: 158-163

33. Cherrington AD, Williams PE, Schulman G, Lacy WW (1981) Differential time course of glucagon effect on glycogenolysis and gluconeogenesis in the conscious dog. Diabetes 30:180-187

34. Lecavalier L, Bolli G, Cryer P, Gerich J (1989) Contributions of gluconeogenesis and glycogenolysis during glucose counterregulation in normal humans. Am J Physiol 256: E844-851

35. Yki-Järvinen H, Koivisto VA (1984) Continuous subcutaneous insulin infusion therapy decreases insulin resistance in type 1 diabetes. J Clin Endocrinol Metab 58: 659-666

36. DeFronzo RA, Simonson D, Ferrannini E (1982) Hepatic and peripheral insulin resistance: a common feature of Type 2 (noninsulin-dependent) and Type 1 (insulin-dependent) diabetes mellitus. Diabetologia 23: 313-319

37. Hother-Nielsen O, Schmitz O, Bak J, Beck-Nielsen H (1987) Enhanced hepatic insulin sensitivity, but peripheral insulin resistance in patients with Type 1 (insulin-dependent) diabetes. Diabetologia 30: 834-840

38. Shulman GI, Williams PE, Liljenquist JE, Lacy WW, Keller U, Cherrington AD (1989) The effect of hyperglycaemia independent of changes in insulin or glucagon on lipolysis in the conscious dog. Metabolism 39: 317-319

39. Gerich JE, Lorenzi M, Bier DM et al. (1976) Effects of physiologic levels of glucagon and growth hormone on human carbohydrate and lipid metabolism. J Clin Invest 57: 877-884

40. Alberti KGMM, Natrass M (1987) The physiological function of glucagon. Eur J Clin Invest 7: 151-154

Received: 12 November 1990

and in revised form: 26 March 1991

Dr. L. Ørskov

Department of Medicine III

Aarhus Amtssygehus

DK-8000 Aarhus C

Denmark 